\section{The Relationship between Flower Age and Seed Production in Hatiora gaertneri and Schlumbergera truncata (Cactaceae)}

\author{
Thomas H. Boyle ${ }^{1}$ \\ Department of Plant, Soil and Insect Sciences, French Hall, University of \\ Massachusetts, Amherst, MA 01003
}

Additional index words. Christmas cactus, Easter cactus, flower longevity, fruit set, seed set

\begin{abstract}
Flowers of two cacti [Hatiora gaertneri (Regel) Barthlott 'Crimson Giant' and Schlumbergera truncata (Haworth) Moran 'Eva'] were pollinated at different times between anthesis and senescence to determine the effect of floral age on seed production. Studies were conducted in a growth chamber $\left(20 \pm 0.5^{\circ} \mathrm{C}\right)$ to minimize temperature effects. Mean flower longevity (time from anthesis to first signs of senescence) was 4.7 days for $S$. truncata and 10.5 days for $H$. gaertneri. Stigmas of both species were receptive to pollination on the day of anthesis. The maximum number of viable seeds per pollinated flower was obtained when flowers of $S$. truncata and $\boldsymbol{H}$. gaertneri were pollinated (respectively) on the second and fourth days after anthesis. For both species, the relationship between floral age and number of viable seeds per pollinated flower was described by a second-degree polynomial. The rate of pollen tube growth in the style was about $1.7 \mathrm{~mm} \cdot \mathrm{h}^{-1}$ for $S$. truncata and about $0.9 \mathrm{~mm} \cdot \mathbf{h}^{-1}$ for $\boldsymbol{H}$. gaertneri. Some senesced flowers of $\boldsymbol{H}$. gaertneri were capable of setting fruit with viable seed. Flowers of $S$. truncata did not set fruit when pollinated during the late phase of flower opening or after they had senesced. Senesced flowers of $S$. truncata failed to set fruit due to an insufficient number of pollen tubes reaching the ovary.
\end{abstract}

One of the critical procedures in most crop breeding programs is production of high-quality seed. Due to labor and time constraints, breeders aim to maximize their efficiency at obtaining seed for further breeding efforts or hybrid seed production. One factor that can affect the yield of viable seeds is the timing of pollen arrival on stigmas. Pollen grains arriving on immature or aged pistils may fail to set fruit or, if fruit set does occur, few viable seeds are produced. Floral age at the time of pollination has been shown to affect percent fruit set and/or seed yields in such diverse taxa as Actinidia deliciosa (González et al., 1995), Buchloe dactyloides (Jones and Newell, 1948), Cyclamen persicum (Ewald and Schwenkel, 1999), Hylocereus spp. (Weiss et al., 1994a), Lilium spp. (Kim and Niimi, 2002), Malus sylvestris (Williams, 1965), Prunus armeniaca (Burgos et al., 1991), and Zea mays (Jones and Newell, 1948). The time of pollination in relation to floral age may influence the extent of pollen germination on the stigma, the rate of pollen tube growth in the style and ovary, and ovule viability. These factors ultimately affect the potential for fruit set and seed production.

Schlumbergera truncata (Christmas cactus) and Hatiora gaertneri (Easter cactus) are two

Received for publication 13 June 2005. Accepted for publication 22 July 2005. Publication 3366 of the Massachusetts Agricultural Experiment Station. This material is based on work supported in part by the Cooperative State Research, Extension, Education Service, U.S. Department of Agriculture, Massachusetts Agricultural Experiment Station, under Project No. 746

${ }^{1}$ To whom reprint requests should be addressed; e-mail tboyle@pssci.umass.edu.e-mail. were used to determine the commencement of anthesis and senescence.

Fruit and seed set in relation to timing of pollination. Plants with mature flower buds (about 1 to $2 \mathrm{~d}$ before opening) were transferred from a greenhouse to the growth chamber. Plants were examined twice daily and each flower was tagged on the day of opening (= day 0 ). Newly opened flowers were tagged on six consecutive days for $S$. truncata and 12 consecutive days for $H$. gaertneri. Flowers of $S$. truncata and $H$. gaertneri were pollinated on the sixth and twelfth day, respectively.

Nonsenesced as well as senesced flowers were pollinated using fresh pollen collected from several cross-compatible genotypes (Boyle, 2001). Each flower was pollinated once. Emasculation was not necessary due to presence of self-incompatibility (Boyle, 1996; Boyle et al., 1994). The experimental procedure yielded flowers ranging from anthesis to senescence in 1-d intervals. Eight or more flowers were pollinated per time interval. Plants were returned to the greenhouse $48 \mathrm{~h}$ after pollination. Fruit were harvested 3 months after pollination for $H$. gaertneri (Boyle et al., 1994) and 8 months after pollination for S. truncata (Boyle et al., 1995). Seeds were cleaned as described previously (Boyle, 1994) and sown in 10-cm-diameter petri dishes containing one layer of blue blotter paper (Anchor Paper Co., St. Paul, Minn.) moistened with deionized water. Each dish contained seeds from one fruit. Dishes were sealed with parafilm and placed in an incubator kept at $25 \pm$ $1{ }^{\circ} \mathrm{C}$ day $/ 22 \pm 1{ }^{\circ} \mathrm{C}$ night with irradiance $(50$ $\pm 8 \mu \mathrm{mol} \cdot \mathrm{s}^{-1} \cdot \mathrm{m}^{-2}$ ) supplied for $12 \mathrm{~h}$ daily by cool-white fluorescent lamps. The numbers of germinated seeds (radicle $\geq 1 \mathrm{~mm}$ ) were recorded $30 \mathrm{~d}$ after sowing. Percent fruit set, number of viable seeds per fruit, and number of viable seeds per pollinated flower [(fraction of fruit set $) \times($ no. viable seeds per fruit $)]$ were calculated for each treatment.

Kinetics of pollen tube growth, fruit set, and seed set. Plants of $H$. gaertneri and $S$. truncata with mature flower buds (about 1 to $2 \mathrm{~d}$ before opening) were transferred from the greenhouse to the growth chamber. Flowers were pollinated 1 or $2 \mathrm{~d}$ after opening using compatible pollen collected from two or more flowers. Each flower was pollinated once. Styles were excised at the point of attachment to the ovaries at various intervals after pollination. Styles remained intact on control plants. Plants were returned to the greenhouse upon completion of the last stylar excision treatment. Ten or more flowers were used for each treatment and treatments were randomized over 4 or more plants.

Style length. Ten flowers of each cultivar were harvested and median longitudinal sections were prepared by removing the ovary walls on both sides of the pistil with the stigmas and style remaining attached to the ovary. Styles were measured from the distal end of the stigma lobes to the ovary.

Effect of flower age on pollen tube growth. Senescent and nonsenescent flowers of $S$. truncata were pollinated using fresh compatible pollen. Pistils were harvested at 40,64 , and $93 \mathrm{~h}$ after pollination and fixed in $95 \%$ 
ethanol and glacial acetic acid ( $3: 1$, by volume) for $\geq 24 \mathrm{~h}$. Styles were softened for $1 \mathrm{~h}$ at 100 ${ }^{\circ} \mathrm{C}$ in $10 \%(\mathrm{w} / \mathrm{v}) \mathrm{Na}_{2} \mathrm{SO}_{3}$, stained overnight in $0.1 \%(\mathrm{w} / \mathrm{v})$ decolorized aniline blue in 0.1 $\mathrm{M} \mathrm{K}_{3} \mathrm{PO}_{4}$ (Martin, 1959), and viewed with an epifluorescence microscope using a filter set for UV-violet waveband excitation (exciter filter BP 395-425, dichromatic beam splitter FT 425 and barrier filter LP 450). Ten styles were examined per time interval.

Data analysis. Percentage data were analyzed by the $\chi^{2}$ test with Yates correction(Yates, 1934). Numbers of viable seeds per fruit were analyzed using the SAS General Linear Model (GLM) procedure (SAS Institute, Inc., Cary, N.C.). Single degree-of-freedom contrasts were used to test for treatment differences in the stylar excision experiment.

\section{Results}

Mean flower longevity was $4.7 \pm 0.3 \mathrm{~d}$ (mean $\pm \mathrm{SD}$ ) for S. truncata 'Eva' and $10.5 \pm$ $0.8 \mathrm{~d}$ (mean $\pm \mathrm{SD}$ ) for $H$. gaertneri 'Crimson Giant'. In both species, senescence was characterized by loss of perianth turgor, fading of petal color, and changes in stigma lobe orientation. During the early phase of flower opening, stigmatic lobes of $H$. gaertneri were oriented at a 30 to $45^{\circ}$ angle to the style and became increasingly reflexed $\left(\geq 90^{\circ}\right)$ as flowers aged. Stigmatic lobes in $S$. truncata were appressed in the early phase of flower opening and oriented at about a $15^{\circ}$ angle to the style at senescence, but remained erect during the entire period of flower opening.

Stigmas of $H$. gaertneri and $S$. truncata were receptive on the day of anthesis (= day 0 ) (Tables 1 and 2). Fruit set for $S$. truncata was $100 \%$ on days 0 to 2 but declined to $30 \%$ on day 4 and finally to $0 \%$ on day 5 . Nonsenesced flowers of $S$. truncata pollinated between day 0 and day 4 produced similar numbers of viable seeds per fruit while those flowers pollinated on day 2 yielded the greatest number of viable seeds per pollinated flower. Flowers of $S$. truncata that were pollinated after senescence failed to set fruit (Table 1). Fruit set was $\geq 84 \%$ for nonsenesced flowers of $H$. gaertneri that were pollinated between days 0 and 11 . Flowers of $H$. gaertneri pollinated between day 0 and day 7 yielded similar numbers of viable seeds per fruit (Table 2). Although seed yields in $H$. gaertneri decreased after day 7 , nearly all of the nonsenesced flowers pollinated between day 8 and day 11 produced viable seeds and $35 \%$ of the senesced flowers formed seedbearing fruit.

The relationship between flower age and seed yields is shown in Fig. 1. Numbers of viable seeds per pollinated flower were converted to percentage values by setting the maximum seed yields (= day 2 for $S$. truncata and day 4 for $H$. gaertneri) to $100 \%$. For both species, the functional relationship between floral age and number of viable seeds per pollinated flower was described by a second-degree polynomial. The regression equation for $S$. truncata is $\mathrm{Y}_{\mathrm{S}}=71.50+28.81 \mathrm{D}_{\mathrm{A}}-8.89 \mathrm{D}_{\mathrm{A}}^{2}$ $\left(r^{2}=0.92\right)$, where $\mathrm{Y}_{\mathrm{S}}$ is the number of viable seeds per pollinated flower and $\mathrm{D}_{\mathrm{A}}$ is the number of days after anthesis. For $H$. gaertneri, the regression equation is $\mathrm{Y}_{\mathrm{S}}=74.18+10.87 \mathrm{D}_{\mathrm{A}}$ $-1.43 \mathrm{D}_{\mathrm{A}}^{2}\left(r^{2}=0.93\right)$.

Styles of $S$. truncata averaged $73.7 \pm 2.0$ $\mathrm{mm}$ (mean $\pm \mathrm{SD}$ ) in length while those of $H$. gaertneri were $24.0 \pm 1.6 \mathrm{~mm}$ (mean $\pm \mathrm{SD}$ ) long, and this difference was highly significant $(P<0.001)$.

For $S$. truncata, stylar excision at $48 \mathrm{~h}$ after pollination or later resulted in $\geq 92 \%$ fruit set and seed yields similar to intact styles (Table 3). When H. gaertneri styles were excised 30 $\mathrm{h}$ after pollination, fruit set was $100 \%$ and seed yields did not differ significantly from intact styles (Table 4). Graphical analysis of the data in Tables 3 and 4 (Fig. 2) indicated that the number of viable seeds per pollinated flower was about $50 \%$ of maximum yields when styles of $S$. truncata and H. gaertneri were excised at 44 and $26 \mathrm{~h}$ (respectively) after pollination.

Relatively few pollen tubes traversed to the base of the styles when senesced flowers of $S$. truncata were pollinated (Fig. 3). At $64 \mathrm{~h}$ after pollination, flowers pollinated beforesenescence had $124.4 \pm 8.4($ mean $\pm \mathrm{SD}$ ) pollen tubes at the base of the style, whereas flowers pollinated after senescence had only $11.6 \pm$
$18.5($ mean $\pm \mathrm{SD})$ pollen tubes at the base of the style (Fig. 3).

\section{Discussion}

Schlumbergera truncata and $H$. gaertneri exhibited quadratic relationships between seed yields and floral age at the time of pollination. These results demonstrate that the probability of viable seed production in these two species is dependent on the timing of pollen arrival on the stigma. Although stigmas of $S$. truncata and $H$. gaertneri were receptive to pollination on the day of anthesis (day 0 ), seed yields per pollinated flower were greatest on day 2 for $S$. truncata and day 4 for $H$. gaertneri (Tables 1 and 2; Fig. 1). The latter two dates coincide with the stage in which the perianths of these species reach their maximum expansion and turgor (Scott et al., 1994). Some cultivars of Malus sylvestris (Williams et al., 1984), Prunus armeniaca (Burgos et al., 1991), and Pyrus communis (Herrero, 1983) exhibit this same trend, with flowers pollinated a few days after anthesis setting more fruit than those pollinated on the day of anthesis. In her study of 'Agua de Aranjuez' pear, Herrero (1983) found that

Table 1. Influence of floral age at the time of pollination on fruit and seed set of Schlumbergera truncata 'Eva'.

\begin{tabular}{lcccc}
\hline $\begin{array}{l}\text { Days from } \\
\text { anthesis to } \\
\text { pollination }\end{array}$ & $\begin{array}{c}\text { Flowers } \\
\text { pollinated } \\
\text { (no.) }\end{array}$ & $\begin{array}{c}\text { Fruit } \\
\text { set } \\
(\%)\end{array}$ & $\begin{array}{c}\text { Viable seeds/ } \\
\text { fruit (no.) }\end{array}$ & $\begin{array}{c}\text { Viable seeds/ } \\
\text { pollinated } \\
\text { flower (no. })^{\mathrm{z}}\end{array}$ \\
\hline $\begin{array}{l}\text { Nonsenesced flowers } \\
0\end{array}$ & 23 & 100 & 84.0 & 84.0 \\
1 & 22 & 100 & 93.0 & 93.0 \\
2 & 29 & 100 & 113.0 & 113.0 \\
3 & 34 & 91 & 111.4 & 29.6 \\
4 & 43 & $30^{y}$ & 98.0 & 0 \\
5 & 8 & $0^{y}$ & -- & 0 \\
$\quad \begin{array}{l}\text { Senesced flowers } \\
4 \text { and 5 }\end{array}$ & 20 & $0^{y}$ & --- & NS \\
F test
\end{tabular}

${ }^{z}$ (Fraction of fruit set $) \times($ number of viable seeds/fruit $)$.

yTreatment significantly different from day $1\left(100 \%\right.$ fruit set) by chi-square test, $P=0.05 ; \chi^{2}=3.84$ for $1 \mathrm{df}$.

${ }^{\mathrm{x}} \mathrm{F}$ test performed on data from days $0,1,2,3$, and 4 .

NS Nonsignificant at $P>0.05$.

Table 2. Influence of floral age at the time of pollination on fruit and seed set of Hatiora gaertneri 'Crimson Giant'.

\begin{tabular}{lcccc}
\hline $\begin{array}{l}\text { Days from } \\
\text { anthesis to } \\
\text { pollination }\end{array}$ & $\begin{array}{c}\text { Flowers } \\
\text { pollinated } \\
(\text { no.) }\end{array}$ & $\begin{array}{c}\text { Fruit } \\
\text { set } \\
(\%)\end{array}$ & $\begin{array}{c}\text { Viable seeds/ } \\
\text { fruit (no.) }\end{array}$ & $\begin{array}{c}\text { Viable seeds/ } \\
\text { pollinated } \\
\text { flower (no. })^{\mathrm{z}}\end{array}$ \\
\hline $\begin{array}{l}\text { Nonsenesced flowers } \\
0\end{array}$ & 31 & $84^{\mathrm{y}}$ & $132.2 \mathrm{ab}^{\mathrm{x}}$ & 111.0 \\
1 & 27 & 100 & $145.8 \mathrm{a}$ & 145.8 \\
2 & 19 & 95 & $140.8 \mathrm{a}$ & 133.8 \\
3 & 28 & 93 & $142.4 \mathrm{a}$ & 132.4 \\
4 & 28 & 100 & $155.0 \mathrm{a}$ & 155.0 \\
5 & 23 & 96 & $142.6 \mathrm{a}$ & 136.9 \\
6 & 18 & 94 & $137.2 \mathrm{a}$ & 129.0 \\
7 & 18 & 100 & $140.8 \mathrm{a}$ & 140.8 \\
8 & 16 & 100 & $110.4 \mathrm{bc}$ & 110.4 \\
9 & 23 & 93 & $92.4 \mathrm{c}$ & 85.9 \\
10 & 8 & 100 & $64.6 \mathrm{~d}$ & 64.6 \\
11 & 9 & 89 & $28.8 \mathrm{e}$ & 25.6 \\
Senesced flowers & & & & 7.1 \\
8 to 11 & 17 & $35^{\mathrm{y}}$ & $20.2 \mathrm{e}$ & $* * *$ \\
\hline
\end{tabular}

${ }^{z}$ (Fraction of fruit set) $\times$ (number of seeds/fruit).

yTreatment significantly different from day 1 ( $100 \%$ fruit set) by chi-square test, $P=0.05 ; \chi^{2}=3.84$ for $1 \mathrm{df}$.

${ }^{x}$ Mean separation by Duncan's multiple range test at $P=0.05$.

${ }^{* * * *}$ Significant $\mathrm{F}$ test at $\alpha \leq 0.001$. 


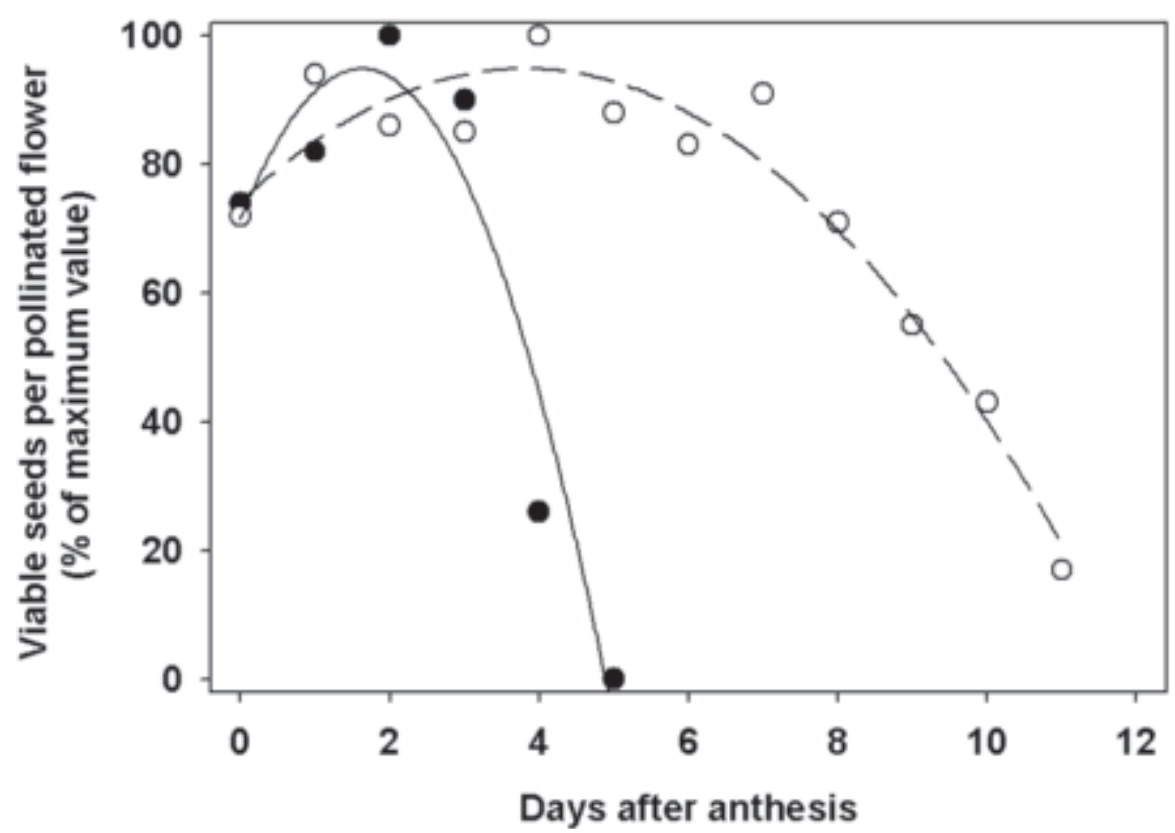

Fig. 1. Influence of flower age on the number of viable seeds per pollinated flower in Schlumbergera truncata 'Eva' ( , solid line) and Hatiora gaertneri 'Crimson Giant' $(\bigcirc$, dashed line).

Table 3. Effect of timing of stylar excision after pollination on fruit set and number of viable seeds per fruit for Schlumbergera truncata 'Eva'.

\begin{tabular}{|c|c|c|c|c|}
\hline $\begin{array}{l}\text { Time of } \\
\text { stylar excision } \\
\text { (hours after } \\
\text { pollination) }\end{array}$ & $\begin{array}{l}\text { Flowers } \\
\text { pollinated } \\
\text { (no.) }\end{array}$ & $\begin{array}{l}\text { Fruit } \\
\text { set } \\
(\%)\end{array}$ & $\begin{array}{l}\text { Viable seeds/ } \\
\text { fruit (no.) }\end{array}$ & $\begin{array}{c}\text { Viable seeds/ } \\
\text { pollinated } \\
\text { flower (no.) }\end{array}$ \\
\hline 24 & 11 & $0^{y}$ & --- & --- \\
\hline 30 & 20 & $0^{\mathrm{y}}$ & --- & --- \\
\hline 36 & 20 & $0^{\mathrm{y}}$ & --- & --- \\
\hline 42 & 20 & $50^{y}$ & 46.4 & 23.2 \\
\hline 48 & 20 & 95 & 106.8 & 101.5 \\
\hline 54 & 22 & 95 & 103.8 & 98.6 \\
\hline 60 & 26 & 92 & 88.8 & 81.7 \\
\hline Intact style & 20 & 100 & 95.8 & 95.8 \\
\hline $\mathrm{F}$ test $^{\mathrm{x}}$ & & & $*$ & \\
\hline \multicolumn{5}{|l|}{ Contrasts } \\
\hline $42 \mathrm{~h}$ vs. intact style & & & ** & \\
\hline $48 \mathrm{~h}$ vs. intact style & & & NS & \\
\hline $54 \mathrm{~h}$ vs. intact style & & & NS & \\
\hline $60 \mathrm{~h}$ vs. intact style & & & NS & \\
\hline
\end{tabular}

${ }^{\mathrm{z}}$ (Fraction of fruit set) $\times($ number of seeds/fruit $)$.

yTreatment significantly different from intact style (control) by chi-square test, $P=0.05 ; \chi^{2}=3.84$ for $1 \mathrm{df}$.

${ }^{\mathrm{x}} \mathrm{F}$ test performed on data from $42,48,54,60$, and intact style (control) treatments.

$\mathrm{NS}^{*, * * *}$ Nonsignificant or significant $\mathrm{F}$ test of contrast between treatments at $0.05 \geq \alpha>0.01$, or $0.01 \geq \alpha>0.001$.

Table 4. Effect of timing of stylar excision after pollination on fruit set and number of viable seeds per fruit for Hatiora gaertneri 'Crimson Giant'.

\begin{tabular}{|c|c|c|c|c|}
\hline $\begin{array}{l}\text { Time of } \\
\text { stylar excision } \\
\text { (hours after } \\
\text { pollination) }\end{array}$ & $\begin{array}{l}\text { Flowers } \\
\text { pollinated } \\
\text { (no.) }\end{array}$ & $\begin{array}{c}\text { Fruit } \\
\text { set } \\
(\%)\end{array}$ & $\begin{array}{l}\text { Viable seeds/ } \\
\text { fruit (no.) }\end{array}$ & $\begin{array}{l}\text { Viable seeds/ } \\
\text { pollinated } \\
\text { flower (no.) }\end{array}$ \\
\hline 16 & 11 & $0^{y}$ & --- & --- \\
\hline 20 & 10 & $10^{y}$ & 16.0 & 1.6 \\
\hline 24 & 11 & $45^{y}$ & 62.0 & 27.9 \\
\hline 30 & 15 & 100 & 108.5 & 108.5 \\
\hline Intact style & 10 & 100 & 94.5 & 94.5 \\
\hline $\mathrm{F}$ test $^{\mathrm{x}}$ & & & $*$ & \\
\hline \multicolumn{5}{|l|}{ Contrasts } \\
\hline $24 \mathrm{~h}$ vs. intact style & & & * & \\
\hline $30 \mathrm{~h}$ vs. intact style & & & NS & \\
\hline
\end{tabular}

${ }^{\mathrm{z}}$ (Fraction of fruit set $) \times($ number of seeds/fruit $)$.

y Treatment significantly different from intact style (control) by chi-square test, $P=0.05 ; \chi^{2}=3.84$ for $1 \mathrm{df}$.

${ }^{\mathrm{x}} \mathrm{F}$ test performed on data from 24,30 , and intact style (control) treatments.

NS,"Nonsignificant or significant F test of contrast between treatments at $0.05 \geq \alpha>0.01$.

flowers pollinated on the day of anthesis set fewer fruit compared with those pollinated two days later, and the difference in fruit set was attributed to lack of stigma maturity on the day of anthesis.

In S. truncata and H. gaertneri, pollen grains germinate within about $0.4 \mathrm{~h}$ after landing on stigmas and pollen tubes penetrate the stigma by about $0.6 \mathrm{~h}$ after pollination (Boyle et al., 1995; T.H. Boyle, unpublished data). Mean pollen tube growth rate in the style was estimated as mean style length $\div$ [time required for half-maximum seed yields -0.6 h]. The estimates are about $1.7 \mathrm{~mm} \cdot \mathrm{h}^{-1}$ for $S$. truncata and about $0.9 \mathrm{~mm} \cdot \mathrm{h}^{-1}$ for $\mathrm{H}$. gaertneri. The rates of pollen tube growth rate in styles of $S$. truncata and $H$. gaertneri are positively correlated with style length but negatively correlated with flower longevity.

Schlumbergera truncata and $H$. gaertneri exhibited dissimilar responses to late pollinations. Between days 3 and 4, percent fruit set in $S$. truncata declined $61 \%$ while the numbers of viable seeds per fruit decreased just 12\% (Table 1). In H. gaertneri, percent fruit set declined only $4 \%$ between days 9 and 11 while numbers of viable seeds per fruit fell $69 \%$ during this period (Table 2). Hylocereus polyrhizus and $H$. costaricensis are two cacti cultivated as fruit crops (Mizrahi et al., 1997), and fruit weight is positively correlated with number of seeds per fruit $\left(r^{2}=0.75\right.$ to 0.81$)$ in these two species (Weiss et al., 1994a). When flowers of $H$. polyrhizus and $H$. costaricensis were pollinated 12 or $24 \mathrm{~h}$ after anthesis, percent fruit set remained at $100 \%$ while fruit weight dropped significantly when pollination was delayed $12 \mathrm{~h}$ (Weiss et al., 1994a). Hence, a delay in pollination had little or no effect on fruit set but markedly decreased seed yields in $H$. gaertneri, $H$. polyrhizus, and $H$. costaricensis.

Some senescent flowers of $H$. gaertneri yielded fruit with viable seeds (Table 2). Under natural conditions, pollinators are unlikely to visit senescent flowers of $H$. gaertneri because access to pollen and/or nectar is thwarted by a flaccid perianth (Scott et al., 1994). However, the fact that senescent flowers of $H$. gaertneri are capable of producing viable seed indicates that the pistil retains its essential functions (stigma receptivity and ovule viability) after perianth senescence. Likewise, flowers of $H$. polyrhizus and $H$. costaricensis are capable of producing seed-bearing fruit when pollinated up to $20 \mathrm{~h}$ after senescence (Weiss et al., 1994a). Senesced flowers of $S$. truncata flowers failed to set fruit (Table 1) due to few pollen tubes reaching the ovary (Fig. 3). Whether this was caused by a reduction in the percentage of pollen grains germinating on the stigma and/or slow pollen tube growth in the style remains to be determined.

Cactus flowers have a reputation of being short-lived. Many arborescent and climbing species of cacti produce large, funnelform, white (or pale) flowers that remain open for $<24$ h(Fleming et al., 1996; Nassar et al., 1997; Weiss et al., 1994a, 1994b). Primack (1985) examined six Cactaceae species growing under greenhouse conditions and found that the average flower longevity was $2.9 \pm 1.8 \mathrm{~d}$ (mean $\pm \mathrm{SD}$ ), with all of the species having flowers that lasting $<6$ d. By comparison, flowers of $H$. gaertneri lasted for 10.5 days, which is an exceptionally long flowering period for a cactus flower. Long-lived flowers are a 


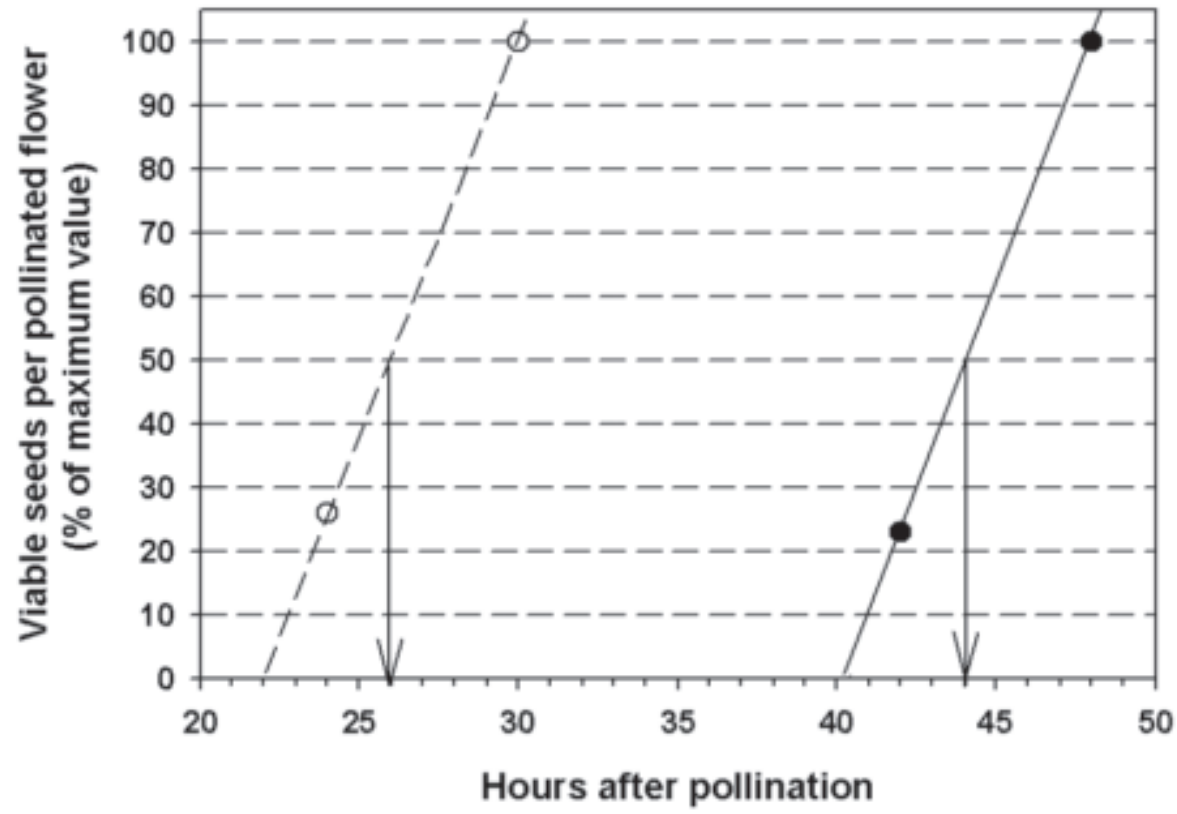

Fig. 2. Time required from pollination to $50 \%$ yield of viable seeds per pollinated flower in Schlumbergera truncata 'Eva' (๑, solid line) and Hatiora gaertneri 'Crimson Giant' ( $\bigcirc$, dashed line).

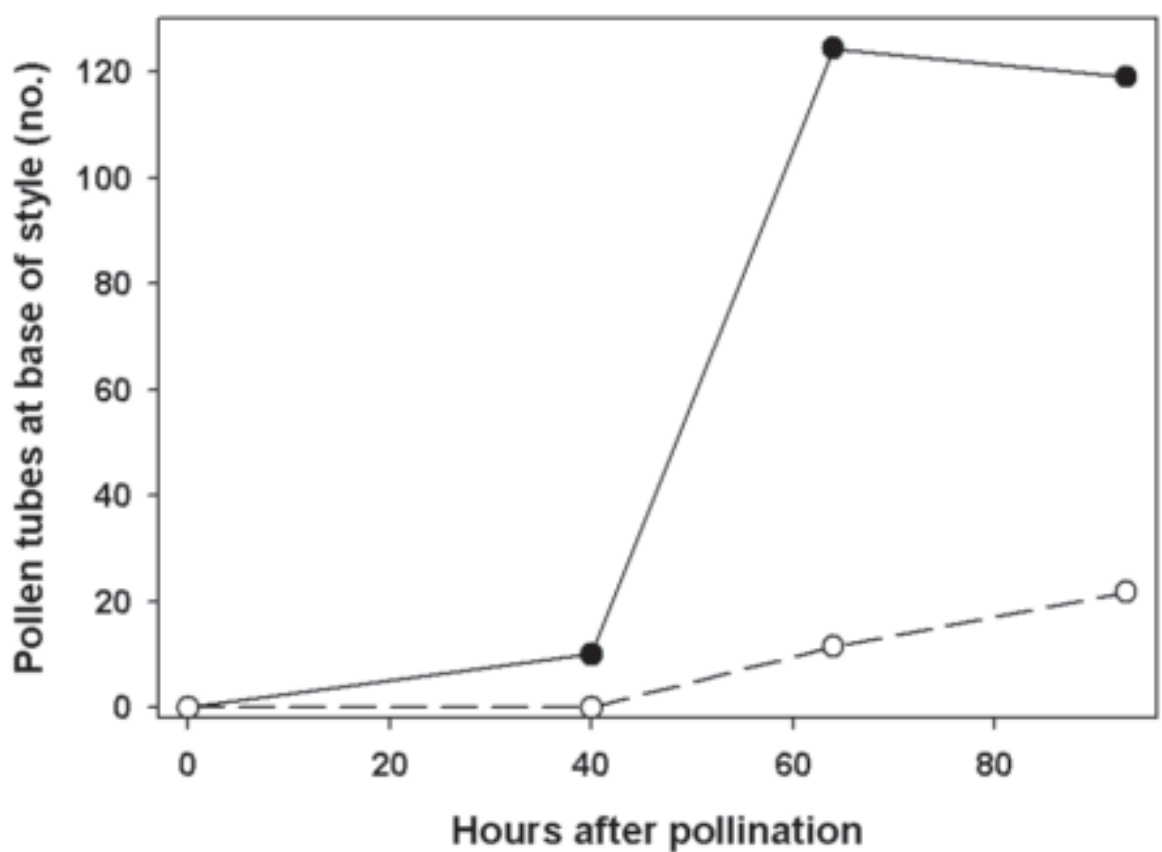

Fig. 3. Number of pollen tubes at the base of the style at different times after pollinating nonsenesced ( solid line) and senesced ( $O$, dashed line) flowers of Schlumbergera truncata 'Eva'.

major investment in terms of water, essential elements and photosynthates (Primack, 1985) and therefore likely serve some purpose for the plant's survival. The long-lived flowers of $H$. gaertneri may enhance the plant's floral display and increase the likelihood of flower visitation by potential pollinators.

\section{Literature Cited}

Anderson, E.F. 2001. The cactus family. Timber Press, Portland, Ore.

Boyle, T.H. 1994. A simple method for extract-
Soc. Hort. Sci. 119:1060-1067.

Burgos, L., J. Egea, and F. Dicenta. 1991. Effective pollination period in apricot (Prunus armeniaca L.) varieties. Ann. Appl. Biol. 119:533-539.

Buxbaum, F. 1953. Morphology of cacti. II. The flower. Abbey Garden Press, Pasadena, Calif.

Buxbaum, F. 1955. Morphology of cacti. III. Fruits and seeds. Abbey Garden Press, Pasadena, Calif.

Ewald, A. and H.G. Schwenkel. 1999. Einfulß von Blütenalter und Genotyp auf den Samenansatz von Cyclamen persicum 'Sylvia'. Gartenbauwissenschaft 64:49-53.

Fleming, T.H., M.D. Tuttle, and M.A.Horner. 1996. Pollination biology and the relative importance of nocturnal and diurnal pollinators in three species of Sonoran Desert columnar cacti. S.W. Nat. 41:257-269.

González, M.A., M. Coque, and M. Herrero. 1995. Stigmatic receptivity limits the effective pollination period in kiwifruit. J. Amer. Soc. Hort. Sci. 120:199-202.

Hartley, G., T.A. Nell, R.T. Leonard, J.E. Barrett, and T.H. Boyle. 1995. Effect of interior light and temperature on longevity of Rhipsalidopsis. Acta Hort. 405:164-169.

Herrero, M. 1983. Factors affecting fruit set in "Agua de Aranjuez’ pear. Acta Hort. 139:91-96.

Jones, M.D. and L.C. Newell. 1948. Longevity of pollen and stigmas of grasses: Buffalograss, Buchloe dactyloides (Nutt.) Engelm., and corn, Zea mays L. J. Amer. Soc. Agron. 40:195-204.

Kim, H.J. and Y. Niimi. 2002. Frequency of viable seeds obtained from several Lilium spp. crosspollinated at different floral stages. J. Jpn. Soc. Hort Sci. 71:231-235.

Martin, F.W. 1959. Staining and observing pollen tubes in the style by means of fluorescence. Stain Technol. 34:125-128.

Mizrahi, Y., A. Nerd, and P.S. Nobel. 1997. Cacti as crops. Hort. Rev. 18:291-319.

Nassar, J.M., N. Ramírez, and O. Linares 1997. Comparative pollination biology of Venezuelan columnar cacti and the role of nectar-feeding bats in their sexual reproduction. Amer. J. Bot. 84:918-927.

Primack, R.B. 1985. Longevity of individual flowers. Ann. Rev. Ecol. Syst. 16:15-37.

Scott, D., T.H. Boyle, and S.S. Han. 1994. Floral development and flower longevity in Rhipsalidopsis and Schlumbergera (Cactaceae). HortScience 29:898-900.

Vasilakakis, M. and I.C. Porlingis. 1985. Effect of temperature on pollen germination, pollen tube growth, effective pollination period, and fruit set of pear. HortScience 20:733-735.

Weiss, J.,A. Nerd, and Y. Mizrahi. 1994a. Flowering behavior and pollination requirements in climbing cacti with fruit crop potential. HortScience 29:1487-1492.

Weiss, J., A. Nerd, and Y. Mizrahi. 1994b. Flowering and pollination requirements in Cereus peruvianus cultivated in Israel. Israel J. Plant Sci. 42:149-158.

Williams, R.R. 1965. The effect of summer nitrogen applications on the quality of apple blossom. J. Hort. Sci. 40:31-41.

Williams, R.R., P. Brain, R.M. Church, and V.A. Flook. 1984. Flower receptivity, pollen transfer and fruit set variations during a single flowering period of ‘Cox's Orange Pippin' apple. J. Hort. Sci. 59:337-347.

Yates, F. 1934. Contingency tables involving small numbers and the $\chi^{2}$ test. J. Royal Stat. Soc. Suppl. 1:217-235. 